\title{
Arte, filosofia e verdade no pensamento de Heidegger
}

\section{Art, philosophy and truth in Heidegger's thought}

\author{
Dnd $^{\circ}$ Felipe Shimabukuro \\ Felipe.Shimabukuro@malix.univ-paris1.fr \\ CAPES | Université Paris 1 - Panthéon-Sorbonne
}

Trata-se, neste artigo, de compreender a relação entre arte, filosofia e verdade no pensamento de Heidegger. Para tanto, traçaremos, num primeiro momento, o modo através do qual a questão da verdade aparece na sua filosofia. Veremos que, para Heidegger, existem duas dimensões diferentes da verdade: a verdade como adequação e a verdade como desvelamento (Unverborgenheit). Em seguida, delimitaremos o modo de relação entre estas duas formas de verdade a partir da noção de desconstrução e, por fim, analisaremos a sua implicação para a compreensão da relação entre verdade, filosofia e arte no pensamento de Heidegger.

PALAVRAS-CHAVE Arte . Filosofia . Verdade . Desconstrução . Ser

In this article, we aim to understand the relation between art, philosophy and truth in Heidegger's thought. To achieve this goal, we are going to outline at first the way that the question of truth appears in his philosophy. We will see that, for Heidegger, there are two different dimensions of truth: truth as correspondence and truth as unhiddenness (Unverborgenheit). Then we will define the mode of relation between these two types of truth from the notion of deconstruction and, at last, we will analyze its implication to the understanding of the relation between truth, philosophy and art in Heidegger's thought.

KEYWORDS Art . Philosophy . Truth . Deconstruction . Being 


\section{Introdução}

No livro Pequeno manual de inestética, o filósofo francês Alain Badiou traça um plano geral dos três esquemas hegemônicos de compreensão da relação entre arte, filosofia e verdade no interior da história da filosofia: didatismo, romantismo e classicismo. A tese do esquema didático é de que só a filosofia é capaz de atingir a verdade. Neste sentido, toda verdade se situaria na exterioridade da arte, ou seja, a arte seria incapaz de alcançar a verdade. Tal esquema remete ao modo através do qual Platão compreende a relação entre arte, filosofia e verdade. No livro X de $A$ república, por exemplo, o filósofo grego nos fornece um princípio de inteligibilidade da relação entre arte, filosofia e verdade através do famoso exemplo das três espécies de cama:

[...] estas três camas constituirão três camas distintas. A primeira é a que existe por natureza, aquela que, segundo meu pensamento, diríamos ser a obra de um deus. Poderia tratar-se de alguém diferente? Ninguém, penso. A segunda cama é a que o marceneiro fabricou. Sim. A terceira cama é a que o pintor fabricou, não é? Sim. Assim, pintor, fabricante de camas, deus, eis os três responsáveis pelas três espécies de camas (PLATÃO, 2002, 597b 5-10)1.

A primeira espécie de cama corresponde à ideia ou eidos que constitui o modelo ideal ou a essência enquanto modo de ser verdadeiro da cama produzido por deus; a segunda espécie de cama diz respeito à existência da cama enquanto cópia do modelo ideal produzida pelo marceneiro; já a terceira espécie de cama remete à aparência da cama criada pelo pintor enquanto cópia da cópia do modelo ideal de cama. Essência, existência e aparência constituem assim os três diferentes graus na escala ontológica que define a hierarquia daquilo que possui mais ou menos ser e verdade na filosofia de Platão. Logo, a Ideia de cama produzida por deus é o ser verdadeiro por excelência situando-se na dimensão ontológica da essência; a existência da cama produzida pelo marceneiro possui um grau de dignidade ontológica inferior à Ideia ou essência de cama, e, por

1 Todas as traduções dos textos de Platão e Aristóteles para o português são minhas e foram feitas a partir da tradução francesa indicada na bibliografia. Todas as traduções dos textos de autores alemães e franceses para o português também são minhas e foram feitas a partir do original indicado na bibliografia, exceto a Crítica da razão pura de Kant que foi traduzida do francês. 
fim, a cama criada pelo pintor possui o menor grau de dignidade ontológica sendo relegada ao âmbito da mera aparência ilusória, daí porque Platão pode escrever: "[A] pintura é uma imitação da aparência ou da verdade? Da aparência. A arte da imitação está, então, bem longe do verdadeiro" (PLATÃO, 2002, $598 b$ 5). Na filosofia de Platão, as categorias ontológicas de essência, existência e aparência correspondem ao esquema do modelo ideal, da boa cópia e do simulacro. Segundo tal esquema, o modelo ideal (Ideia/essência) constitui o ser verdadeiro e só o filósofo é capaz de atingi-lo, ao passo que a arte se situaria no domínio do simulacro enquanto mera aparência ilusória. A condenação platônica da arte como incapaz de verdade se consagrou através do famoso tema da expulsão dos poetas da cidade ideal no livro III de $A$ república:

[...] se um homem capaz por seu talento de transformar-se de mil maneiras e de imitar todos os tipos de coisas viesse pessoalmente à nossa cidade com o projeto de representar suas composições poéticas, nós o veneraríamos como um ser sagrado, maravilhoso, delicioso, mas lhe diríamos que não há um homem como ele na nossa cidade, e que ele não está em conformidade com a lei desta cidade. Nós o enviaríamos a outra cidade, não sem ter untado sua cabeça de perfume e de tê-lo coroado com tranças de lã (PLATÃO, 2002, 398a 2-9).

Por outro lado, a tese do esquema romântico seria oposta à tese do didatismo: só a arte é capaz de alcançar e revelar a verdade. Para Badiou, tal tese se encontraria de modo emblemático no pensamento de Heidegger. No texto A origem da obra de arte (1935/36), por exemplo, pode-se ler a seguinte afirmação: "a arte é um devir (Werden) e um acontecer (Geschehen) da verdade" (HEIDEGGER, 1980, p. 57). Badiou menciona ainda, en passant e sem mais, que, em solo francês, a tese do esquema romântico teria sido retomada recentemente por Philippe Lacoue-Labarthe e Jean-Luc Nancy e seu conceito de absolu littéraire. Por fim, a tese do esquema clássico é, assim como no esquema didático, de que a arte não é capaz da verdade, no entanto isso não seria um problema à medida que a arte não possuiria uma função ontológico-epistemológica de revelação do ser e da verdade. Para o classicismo a arte teria uma função terapêutica no tratamento das afecções da alma, tese formulada pela primeira vez na Poética de Aristóteles através de seu conceito de catharsis: “A tragédia é então a imitação 
de uma ação nobre (...) esta imitação é executada por personagens que agem e não utilizam a narração, e, através da piedade e do temor ela opera a purificação catharsin das emoções deste gênero" (ARISTÓTELES, 2002, 1449a 25-28).

De modo que, para Badiou, "didatismo, romantismo e classicismo são os esquemas possíveis do nó entre arte e filosofia” (BADIOU, 2011, p. 14). No século $\mathrm{XX}$, estes três esquemas ainda seriam dominantes orientando o modo através do qual a relação entre arte, filosofia e verdade é pensada no interior do marxismo, da hermenêutica de matriz heideggeriana e na psicanálise: "Ora, é claro que em matéria de pensamento sobre a arte o marxismo é didático, a psicanálise clássica e a hermenêutica heideggeriana romântica" (BADIOU, 2011, p. 15).

Para Badiou, a prova de que o marxismo é didático se encontra de modo exemplar no teatro de Brecht: "para Brecht, há uma verdade geral e extrínseca, uma verdade de caráter científico. Esta verdade é o materialismo dialético (...). Esta verdade, na sua essência, é filosófica, e o 'filósofo' é o personagem-guia dos diálogos didáticos de Brecht" (BADIOU, 2011, p. 15). No que se refere ao esquema clássico, tanto a psicanálise freudiana quanto lacaniana compreenderiam a relação entre filosofia, arte e verdade em chave aristotélica: "A psicanálise é aristotélica, absolutamente clássica. Para se convencer disto, basta reler tanto os ensaios de Freud sobre a pintura quanto os de Lacan sobre o teatro e a poesia" (BADIOU, 2011, p. 17). Por fim, a figura maior do esquema romântico no século XX seria a hermenêutica heideggeriana: "Que a hermenêutica heideggeriana ainda seja romântica é, em minha opinião, evidente" (BADIOU, 2011, p. 17).

$\mathrm{Na}$ opinião de Badiou é evidente que a hermenêutica heideggeriana é romântica, ou seja, para Heidegger só a arte é capaz da verdade. No entanto, e se aquilo que é aparentemente evidente e óbvio não fosse realmente tão evidente e óbvio quanto gostaríamos de pensar e admitir? E se o pensamento só começasse realmente a pensar à medida que problematiza e coloca em questão aquilo que para nós possui o estatuto e a validade do óbvio e autoevidente? Não seria esta operação de problematização dos pressupostos autoevidentes e óbvios do pensamento um gesto filosófico que estaria na origem de algumas das experiências intelectuais mais importantes da história da filosofia moderna e contemporânea? A dúvida metódica de Descartes, a revolução copernicana de Kant, a renovação da gramática filosófica de Hegel, o colocar em questão do valor dos valores morais de Nietzsche, a redução fenomenológica de Husserl e Heidegger, o afastamento dos preconceitos de Bergson, o pensamento sem Imagem de Deleuze, a desconstrução de Derrida: não seriam estas operações um modo de nos dizer que o primeiro gesto filosófico par excellence de todo pensamento ra- 
dical consiste na problematização daquilo que aparece para o pensamento como óbvio e evidente? A história da filosofia moderna e contemporânea nos mostra que a problematização de um conjunto de pressupostos autoevidentes do pensamento é um movimento necessário a todo pensar radical. Tudo se passa, como dizia Deleuze, "como se o pensamento só pudesse começar a pensar, e recomeçar sempre, liberado da Imagem e dos postulados" (DELEUZE, 2011, p. 173). A fim de problematizar a tese de Badiou segundo a qual a hermenêutica heideggeriana é evidentemente romântica, será necessário compreender as seguintes questões: 1) Como aparece a questão da verdade na filosofia de Heidegger?; 2) Como a concepção heideggeriana de verdade se articula com a filosofia e a arte?

\section{O conceito metafísico de verdade segundo Heidegger}

A edição completa das obras de Heidegger (Gesamtausgabe) possui um estatuto problemático devido à sua grande extensão: 102 volumes! Um dos maiores problemas reside na dificuldade de traçar e delinear de modo rigoroso e exato o modo através do qual Heidegger articula determinados problemas e questões ao longo de toda sua obra, visto que esta longa extensão implica em um grande trabalho de erudição no momento de detectar as diferentes formas de articulação, abandono, rearticulação, retomada e mudança de tratamento de uma mesma questão e da série de problemas a ela relacionada. Não é minha intenção, no presente artigo, traçar de modo rigoroso e minucioso todas as articulações, abandonos, rearticulações e mudanças de direção da questão da verdade ao longo dos 102 volumes da Gesamtausgabe ${ }^{2}$. Limitar-me-ei aos principais desdobramentos e aspectos do problema da verdade no pensamento de Heidegger tendo em vista o nosso problema: a relação entre arte, filosofia e verdade.

\footnotetext{
2 A questão da verdade aparece em diferentes momentos e passagens da Gesamtausgabe. Tal questão é desenvolvida de forma mais sistemática principalmente em quatro textos segundo o número do volume da Gesamtausgabe (abreviada como GA) e o ano de aparição: Lógica. A questão sobre a verdade (GA 21, 1925/1926), Da essência da verdade (GA 9, p. 177-202, 1930), A doutrina platônica da verdade (GA 9, p. 203- 238, 1931/32/40), Da essência da verdade. O mito da caverna e Teeteto de Platão (GA 34, 1931/32). Além destes textos, a questão da verdade é retomada em diversas outras passagens da edição completa, dentre as quais as mais relevantes são: Ser e tempo (\$44, p. 212-230, 1927), Os fundamentos metafísicos iniciais da lógica a partir de Leibniz (GA 26, 1928), Introdução à filosofia (GA 27, p. 44-122, 1911-1944), A origem da obra de arte (em Holzwege, p. 21-64 - 1935/36), Perguntas fundamentais da filosofia (GA 45, 1937/38), Para a interpretação de Nietzsche II (GA 46, 1938/39), A teoria de Nietzsche da vontade de potência como conhecimento (GA 47, 1939), Contribuições à filosofia (GA 65, p. 293-392, 1936/38).
} 
O conceito metafísico de verdade encontra-se, em sua formulação mais clara e compreensível, na obra maior de Heidegger: Ser e tempo. No §44, Heidegger apresenta o conceito metafísico de verdade a partir de três teses:

Três teses caracterizam a compreensão tradicional da essência da verdade [...] 1. O "lugar" (Ort) da verdade é a proposição (Aussage) (o juízo [Urteil]). 2. A essência da verdade reside na "adequação" (Übereinstimmung) do juízo com o seu objeto. 3. Aristóteles, o pai da lógica, atribuiu ao juízo o lugar originário da verdade, assim como conduziu a definição da verdade à via da “adequação (HEIDEGGER, 2001, p. 214).

Segundo a primeira tese, toda verdade é a verdade de uma proposição ( $A u s$ sage) ou juízo (Urteil). Heidegger utiliza os termos Aussage e Urteil como sinônimos que servem para traduzir a interpretação clássica daquilo que Aristóteles chama de logos apophantikos. Segundo o filósofo grego em De interpretatione, "não é toda proposição que é apofântica (apophantikos), mas aquela em que se pode dizer que há verdade (aletheuein) ou falsidade (pseudesthai)" (ARISTÓTELES, 2007, 17a 2-4). Assim, toda verdade é a verdade de um juízo ou proposição que pode ser verdadeira ou falsa, ou seja, não há verdade fora de um logos apophantikos passível de ser verdadeiro ou falso. De acordo com a segunda tese, uma proposição ou juízo é verdadeiro ou falso se ele corresponde ou não ao estado de coisas do mundo, ou seja, se existe uma adequação entre nossas proposições e juízos e os objetos do mundo aos quais se referem. Se digo, por exemplo, "o computador é branco", esta proposição é verdadeira se o computador for realmente branco, ao passo que se o computador não for branco, minha proposição é falsa. Tanto o discurso do senso comum quanto da ciência e da filosofia se move, de modo hegemônico e normativo, no interior desta compreensão da verdade como adequação de uma proposição que descreve ou representa corretamente o estado de coisas do mundo, a realidade. O termo que os filósofos alemães utilizam para descrever tal relação entre a proposição e o estado de coisas do mundo é "Übereinstimmung", tradução alemã do termo grego omoiosis, cuja tradução latina é adaequatio ${ }^{3}$. Heidegger utiliza estes três

3 Heidegger utiliza prioritariamente o termo Übereinstimmung para descrever o conceito clássico de verdade como adequação. No entanto, em diversas passagens de sua obra ele utiliza o termo Richtigkeit, que, no contexto de seu pensamento, é um sinônimo de Übereinstimmung no que se refere à verdade como adequação. 
termos como sinônimos quando se trata de descrever o conceito de verdade como adequação: "verdade enquanto Übereinstimmung, adaequatio, omoiosis" (HEIDEGGER, 2001, p. 215). Finalmente, a terceira tese consiste na ideia de que Aristóteles é o responsável pelo estabelecimento das duas primeiras teses do conceito clássico de verdade.

O conceito metafísico de verdade como adequação possui diferentes formulações ao longo da história da filosofia. Platão, no diálogo Crátilo, por exemplo, diz através do personagem Sócrates: "Aquele que diz as coisas como elas são é verdadeiro, e aquele que as diz como não são é falso? Sim” (PLATÃO, 1967, $385 b)^{4}$. Aristóteles, por sua vez, retoma a formulação platônica de modo mais completo em sua Metafísica: "Dizer do ser que ele não é, ou do não-ser que ele é, é o falso; dizer do ser que ele é, e do não-ser que ele não é, é o verdadeiro; de modo que aquele que diz de um ser que ele é ou que ele não é, dirá o que é verdadeiro ou o que é falso" (ARISTÓTELES, IV, 7, 1011 b 25-27). Tomás de Aquino, um dos filósofos mais importantes e representativos da Idade Média, formula o conceito de verdade em termos de adequação entre a coisa e a inteligência: "a verdade é a adequação entre a coisa e a inteligência" (TOMÁS DE AQUINO, 1999, p. 275). Posteriormente, Kant, na Crítica da razão pura, define o conceito clássico de verdade como adequação entre o conhecimento e seu objeto: "O que é a verdade? A definição nominal da verdade, que é a adequação (Übereinstimmung) do conhecimento com seu objeto" (KANT, 1992, A 58, B 82) $)^{5}$. Na pequena Ciência da lógica da Enciclopédia, Hegel também reconhece o conceito clássico de verdade como adequação (Übereinstimmung) do objeto com nossas representações: "normalmente chamamos de verdade a adequação (Übereinstimmung) do objeto com as nossas representações" (HEGEL, 2003, p. 86) ${ }^{6}$. Do mesmo modo, Bergson, em O pensamento e o movente, reconhece que o conceito hegemônico e normativo de verdade consiste na adequação ou concordância de nossos juízos com a realidade:

4No diálogo $O$ sofista, Platão define a falsidade do seguinte modo: "um discurso é falso, se ele afirma que o que é não é e que o que não é é” (240e). Desta definição podemos deduzir que um discurso é verdadeiro se ele afirma que o que é é e que o que não é não é.

5 Ainda sobre o conceito de verdade como adequação na Crítica da razão pura: "verdade, ou seja, (...) a adequação de nosso conhecimento com os objetos" (A 237, B 296). Em outra passagem: "a verdade, ou seja, (...) a adequação de nossos conceitos com o objeto" (A 642, B 670).

6Embora não abandone totalmente o conceito de verdade como adequação, Hegel é, talvez, o primeiro a operar uma inovação fundamental em relação à noção de adequação, pois, já não se trata mais para ele da adequação entre dois elementos (proposições e estado de coisas), mas de um conteúdo consigo mesmo. Tal seria o conceito filosófico de verdade para Hegel: "no sentido filosófico (...) a verdade significa, dito de modo abstrato em geral, a adequação (Übereinstimmung) de um conteúdo consigo mesmo" (HEGEL, 2003, p. 86) 
O que é um juízo verdadeiro? Chamamos de verdadeira a afirmação que concorda com a realidade. Mas em que consiste esta concordância? Nós gostamos de ver nela algo como a semelhança do retrato com o modelo: a afirmação verdadeira seria aquela que copiaria a realidade (...). Esta concepção da verdade é natural para o nosso espírito e natural também para a filosofia ${ }^{7}$ (BERGSON, 2013, p. 244, 246).

No século XX, alguém como Wittgenstein, um dos filósofos mais importantes e influentes do século, ainda adota, ao menos no Tractatus Logico-Philosophicus, o conceito metafísico de verdade como adequação (Übereinstimmung) entre a proposição como sentido (Sinn) ou imagem (Bild) e a realidade (Wirklichkeit) enquanto estado de coisas (Sachverhalt) do mundo: "a verdade ou falsidade existe na adequação (Übereinstimmung) ou não adequação de seu [da proposição] sentido (imagem) com a realidade" (WITTGENSTEIN, 1961, proposição 2.222).

As principais formulações do conceito de verdade como adequação ao longo da história da filosofia poderiam ser resumidas do seguinte modo: adequação entre ser e pensar (dizer ou pensar que o ser é e que o não ser não é), adequação entre a coisa (res) e o intelecto (intellectus), adequação entre o objeto (Gegenstand) e nosso conhecimento (Erkenntnis), adequação entre o objeto (Gegenstand) e nossas representações (Vorstellungen), adequação entre o estado de coisas ( $\mathrm{Sa}$ chverhalt) do mundo e nossas proposições (Aussagen) ou juízos (Urteile), adequação entre a realidade e nossos enunciados, entre as palavras e as coisas.

Apesar das diferentes formulações do conceito de verdade como adequação, a tese de que o lugar da verdade é a proposição e de que a verdade consiste numa adequação entre proposição e estado de coisas do mundo permanece inalterada e intacta, constituindo-se como o modo hegemônico e normativo de se compreender a verdade no pensamento ocidental. Em $A$ doutrina platônica da verdade, Heidegger é claro neste ponto:

7 Apesar de reconhecer que o conceito de verdade como adequação é dominante no pensamento ocidental, Bergson mostra como William James problematiza tal conceito a partir de uma concepção performativa da linguagem. Se o conceito de verdade como adequação pressupõe o conceito de pensamento enquanto enunciação de juízos ou proposições que descrevem ou representam a realidade através da linguagem, o conceito performativo de linguagem compreende que a verdade de um juízo ou proposição reside menos na descrição ou representação correta da realidade, do que na produção, criação ou desencadeamento de certo modo de agir. No texto Pragmatismo, James afirma: "Peirce, após salientar que nossas crenças são, realmente, regras de ação, dizia que, para desenvolver o significado de uma pensamento, necessitamos apenas determinar que conduta está apto a produzir: isto é para nós o seu único significado" (JAMES, 1979, p. 18). 
"Verdade" significa para o pensamento ocidental desde há muito tempo a adequação (Übereinstimmung) da representação do pensamento com a coisa: adaequatio intellectus et rei (...) A proposição do juízo do entendimento é o lugar da verdade e da falsidade e da diferença entre elas. A proposição é verdadeira à medida que corresponde ao estado de coisas (Sachverhalt), sendo, portanto, omoiosis (...). A partir de então [de Platão] a essência da verdade enquanto correção (Richtigkeit) do representar da proposição torna-se hegemônico e normativo para todo o pensamento ocidental(HEIDEGGER, 2004a, p. 218, p. 232).

O conceito metafísico de verdade como adequação tornou-se o modo hegemônico e normativo de compreensão da verdade não somente para a filosofia, mas também para o senso comum e a ciência. A psicanálise, por exemplo, uma das experiências intelectuais mais importantes do século $\mathrm{XX}$, embora tenha renovado de maneira radical o modo como entendemos categorias decisivas do pensamento contemporâneo como sujeito, sonho, desejo e sexualidade, permanece altamente tradicional no que diz respeito à categoria de verdade, visto adotar o conceito de verdade como adequação como algo óbvio e autoevidente sem problematizá-lo. Para Freud, em Nova sequência de conferências para a introdução à psicanálise, o objetivo da ciência é a verdade enquanto adequação: "Nós chamamos de verdade esta adequação (Übereinstimmung) com o mundo exterior real. Ela permanece o objetivo do trabalho científico" (FREUD, 1990, p. 184). No Seminário I - Os escritos técnicos de Freud, Lacan fala da verdade aceitando as duas primeiras teses sobre o conceito clássico de verdade expostas por Heidegger no $\S 44$ de Ser e tempo: 1) o lugar da verdade é a proposição (a palavra). 2) a verdade consiste em uma adequação:

É a palavra (la parole) que instaura a mentira na realidade. E é precisamente porque ela introduz aquilo que não é, que ela pode introduzir também aquilo que é. Antes da palavra, nada é, nem não é. Tudo já está aí, sem dúvida, mas é somente com a palavra que há coisas que são - que são verdadeiras ou falsas, ou seja, que são - e coisas que não são. É com a dimensão da palavra que a verdade se aprofunda no real. Não há nem verdadeiro nem falso antes da palavra. Com ela se introduz a verdade, e a mentira também (LACAN, 1975, p. 254). 
Recapitulando: as duas primeiras teses sobre a verdade, expostas no $\S 44$ de Ser e tempo, nos mostram que, para Heidegger, o conceito metafísico de verdade, que se tornou hegemônico e normativo para o pensamento ocidental constituindo um dos fundamentos de sua racionalidade, define-se como adequação entre nossas proposições ou representações e o estado de coisas do mundo. A terceira tese, no entanto, segundo a qual Aristóteles teria estabelecido tal conceito de verdade é objeto de hesitação no caminho de pensamento de Heidegger, isso porque em A doutrina platônica da verdade, o filósofo alemão remete a Platão, e não a Aristóteles, o estabelecimento do conceito de verdade como adequação e a transformação da verdade como aletheia (desvelamento) em omoiosis (adequação): "Ao pensamento de Platão segue-se uma transformação da essência da verdade, tal transformação deu início à história da metafísica" (HEIDEGGER, 2004a, p. 237). Assim, se em Ser e tempo Heidegger atribui a Aristóteles a instauração do conceito de verdade como adequação, em $A$ doutrina platônica da verdade ele remete a Platão o estabelecimento de tal conceito de verdade. Embora Heidegger hesite quanto à origem genealógica do conceito de verdade remontar a Platão ou Aristóteles, ele nunca hesita em relação ao conteúdo das duas primeiras teses que definem a verdade como adequação, ou seja, Heidegger jamais modifica sua posição sobre estas teses ao longo de sua experiência intelectual.

\section{O conceito heideggeriano de verdade como desvelamento}

O conceito metafísico de verdade estabelecido por Platão e Aristóteles se tornou hegemônico e normativo para o pensamento ocidental e comporta duas teses: 1) o lugar da verdade é a proposição, o juízo, ou seja, toda verdade é a verdade de uma proposição. 2) a verdade da proposição consiste em uma adequação ao estado de coisas do mundo ao qual se refere. Heidegger problematiza estas duas teses do conceito metafísico de verdade. As teses de Heidegger sobre a verdade, que consistem em uma tomada de posição em relação às duas teses do conceito metafísico de verdade como adequação, poderiam ser formuladas do seguinte modo: 1) o lugar originário da verdade não é a proposição, ou seja, há uma dimensão da verdade que não se reduz à verdade de uma proposição. 2) a verdade, em seu sentido originário, não consiste em uma adequação, mas em um desvelamento (Unverborgenheit) ${ }^{8}$.

80 conceito heideggeriano de verdade como desvelamento é construído a partir da interpretação do termo grego aletheia. Ao longo de sua experiência intelectual, Heidegger utiliza diferen- 
O que significa dizer que o lugar originário da verdade não é a proposição, o juízo? O que significa dizer que a verdade consiste originariamente em um desvelamento e não em uma adequação? Isto significa dizer que existe uma condição anterior que possibilita a enunciação de proposições e juízos e sua comparação com o estado de coisas do mundo que atesta a adequação (verdade) ou inadequação (falsidade) da proposição com a realidade. Para que possamos emitir uma proposição do tipo "o computador é branco" e depois verificar se ela é verdadeira ou falsa, é preciso que de algum modo tal computador já tenha se desvelado, já tenha aparecido e se mostrado como fenômeno acessível para que, posteriormente, seja possível emitir juízos em que o computador é representado pela palavra "computador" enquanto sujeito de uma frase e passível de predicações. Isto quer dizer que podemos nos relacionar com o computador sem que enunciemos nenhum juízo sobre ele através de uma frase com sujeito, verbo e predicado. Em outros termos, os juízos que emitimos sobre o computador são sempre posteriores ao desvelamento e à aparição do ente computador. A verdade como desvelamento é, assim, da ordem do antepredicativo, ou seja, anterior aos modos de predicação enquanto ligação do sujeito ao predicado em uma proposição. Neste sentido, a verdade como adequação é derivada e pressupõe a verdade como desvelamento:

A adequação (Übereinstimmung) do nexus com o ente e sua concordância com ele não tornam primariamente o ente acessível enquanto tal. Este [o ente] precisa primeiramente enquanto um possível sujeito de uma determinação predicativa já estar aberto antes desta predicação e para ela. A predicação precisa, para se tornar possível, ancorar-se num tornar-se aberto (Offenbarmachen), que não tem um caráter predicativo. A verdade da proposição está enraizada em uma verdade mais originária (desvelamento), em uma abertura antepredicativa do ente (HEIDEGGER, 2004b, p. 130).

No contexto de Ser e tempo e da analítica existencial do Dasein, o conceito originário de verdade como desvelamento possui duas funções críticas: 1) mostrar

tes termos para falar de sua interpretação da verdade como aletheia: Unverborgenheit (desvelamento), Entbergung (desencobrimento), Entdecktheit (descobrimento), Offenbarkeit (abertura), sich zeigen (mostrar-se). Todos estes termos remetem à ideia de aletheia que, no fundo, é a forma como Heidegger compreende o fenômeno no sentido fenomenológico do termo. 
o primado da atitude "prática" em relação à atitude "teórica". 2) mostrar o caráter derivado da relação ontológicoepistemológica sujeito-objeto em relação ao caráter originário do Dasein e do mundo, daí porque "Sujeito e objeto não coincidem em nada com Dasein e mundo" (HEIDEGGER, 2001, p. 60). A fim de compreender estas duas funções críticas do conceito de verdade como desvelamento, faz-se necessária uma breve reconstituição do contexto ao qual elas pertencem.

A única questão que atravessa toda a experiência intelectual de Heidegger é a questão do ser (Seinsfrage). Em Ser e tempo, antes de abordar diretamente tal questão, a analítica existencial do Dasein aparece como momento preparatório e preliminar da questão do ser. Trata-se de tematizar as estruturas existenciais do modo de ser do Dasein como ele se dá primeiramente e na maior parte do tempo em sua existência concreta cotidiana. Em sua cotidianidade, o Dasein existe sob a forma daquilo que Heidegger chama de Besorgen, ou seja, o mundo de suas ocupações e tarefas cotidianas. No cotidiano, primeiramente e na maior parte do tempo o Dasein entretém uma atitude "prática" junto aos entes do mundo: as coisas. As coisas que vêm ao encontro do Dasein em seu cotidiano não se mostram, não aparecem como objetos enquanto representação de um sujeito, mas como Zeug (instrumento, ferramenta, utensílio). Em outros termos, as coisas se desvelam em seu modo de ser enquanto instrumento entendido como meio utilizado para se realizar algo. Neste sentido, uma caneta não se desvela, não se abre, não aparece enquanto fenômeno, primeiramente e na maior parte das vezes, como um objeto representado por um sujeito e que pode ser analisado pelo olhar contemplativo que toma a caneta como uma substância que possui propriedades essenciais e acidentais passíveis de serem descritas através de proposições e juízos. Primeiramente e na maior parte das vezes a caneta se desvela como um instrumento que serve para escrever, e nisto consiste o modo de ser primário da caneta enquanto caneta. Heidegger define o modo de ser da coisa enquanto instrumento como Zuhandenheit (aquilo que está na mão sendo utilizado para realizar uma finalidade): "O modo de ser do instrumento (Zeug), em que ele se abre a partir de si mesmo, nós chamamos de Zuhandenheit" (HEIDEGGER, 2001, p. 69). Heidegger utiliza cuidadosa e intencionalmente o termo Zuhandenheit porque em alemão ele dá a ideia de algo que está na mão ( $Z u$-hand) sendo utilizado para realizar uma finalidade em oposição à Vorhandenheit, que comporta a ideia daquilo que está diante da mão (Vor-hand) disponível para o olhar contemplativo de um sujeito que toma o ente como objeto substancial analisável em suas propriedades. O Dasein escreve com a caneta enquanto instrumento. Um sujeito jamais poderá escrever com a representação da caneta como objeto. No texto Sobre a essência da verdade, Heidegger exemplifica tal diferença entre a coisa enquanto instrumento e o objeto enquanto 
representação de uma proposição se servindo do exemplo de uma moeda: "A moeda é de metal. A proposição não é de modo algum material. A moeda é redonda. A proposição não tem de modo algum o modo espacial. Com a moeda pode-se comprar algo. A proposição sobre a moeda nunca é um meio de pagamento" (HEIDEGGER, 2004c, p. 183). O modo de ser da caneta enquanto instrumento remete à atitude "prática" de um fazer que se serve de algo, prioritariamente com a mão, para realizar uma finalidade, ao passo que o modo de ser da caneta como objeto representado por um sujeito através de proposições remete à atitude "teórica" do olhar contemplativo. Neste sentido, o desvelamento do ente enquanto instrumento inserido em nossas ocupações e tarefas cotidianas precede as proposições de um sujeito que representa os entes enquanto objetos do conhecimento. A relação do Dasein com os instrumentos do mundo das ocupações cotidianas é primário e a relação epistemológica do sujeito-objeto só aparece como modo derivado de interrupção das ocupações cotidianas com o instrumento. É neste sentido que a verdade enquanto desvelamento da coisa como instrumento de nossas atividades "práticas" no cotidiano constitui uma crítica do conceito de verdade como adequação da atitude "teórica" que concebe o ente como objeto de nossas representações através de proposições no âmbito epistemológico.

Para Heidegger, um instrumento utilizado pelo Dasein nunca é um ente isolado ao modo do objeto representado por um sujeito. Um instrumento está desde sempre inserido em um conjunto de instrumentos. Assim, um instrumento se define em seu ser como uma coisa que cumpre uma finalidade remetendo sempre a outros instrumentos formando um conjunto organizado de instrumentos: "Tomado rigorosamente, nunca 'existe' um instrumento. Ao ser do instrumento pertence desde sempre um todo de instrumentos no interior do qual um instrumento pode ser o que ele é. O instrumento é essencialmente 'algo para..." (HEIDEGGER, 2001, p. 68). O que Heidegger quer dizer é que a caneta, enquanto instrumento que serve para escrever, só pode aparecer e se desvelar como fenômeno "caneta" à medida que entretém uma relação com o papel em que se escreve. O papel, por sua vez, só se desvela remetendo à mesa sobre a qual se encontra, a mesa remetendo à cadeira sobre a qual quem escreve se senta, o papel, a caneta, a cadeira e a mesa remetem à lâmpada que permite enxergá-los, e todos estes instrumentos remetem ao instrumento escritório que serve para o trabalho de escrever. Poderíamos ir mais longe dizendo que o escritório remete ao instrumento apartamento que serve para morar, o apartamento remete à rua que serve para chegar ao apartamento, a rua remete ao bairro em que ela se encontra, o bairro à cidade, à cidade ao país, o país ao continente, o continente à Terra, a Terra aos outros planetas e estes, finalmente, ao mundo. 
Assim, para que a caneta possa aparecer como instrumento caneta, é preciso que previamente o mundo já tenha se desvelado e aberto como mundo. Como o mundo não é nenhum ente específico, mas a totalidade do ente, ele jamais poderá se desvelar em carne e osso como um ente, e, no entanto, ele é a condição de desvelamento de todo ente enquanto tal. É neste sentido que o Dasein é um ser-no-mundo e que "este fenômeno [...] é o fundamento do fenômeno originário da verdade" (HEIDEGGER, 2001, p. 219). Ou seja, a verdade originária como desvelamento do ente enquanto instrumento só acontece na medida em que o mundo já se desvelou, o que Heidegger chama de abertura do mundo, sentido fundamental do $D a$ do termo Dasein. No entanto, o mundo, primeiramente e na maior parte do tempo, permanece velado no sentido de escondido e dissimulado, ele se mantém retraído à medida que não é um ente e, portanto, não se desvela como os entes enquanto instrumentos. Nunca encontraremos o mundo como encontramos uma caneta ou uma moeda. Assim, o serno- mundo enquanto constituição fundamental do Dasein no cotidiano de suas ocupações "práticas" junto aos instrumentos e aos outros é anterior e originário em relação ao esquema "teórico-epistemológico" e derivado do sujeito que representa objetos através de proposições e juízos: "Conhecer é um modo do Dasein fundado no ser-no-mundo" (HEIDEGGER, 2001, p. 62). Em outros termos, o instrumento remete à ideia de um sistema de relações segundo o modelo de um holismo semântico em oposição ao objeto concebido segundo a ideia de certo atomismo que toma os objetos isoladamente ao modo de um dicionário que compreende as palavras de forma isolada e independentemente dos contextos nos quais são utilizadas. Neste sentido, o mundo é concebido segundo o modelo de um contexto, de um conjunto organizado enquanto sistema de relações no interior do qual cada instrumento recebe seu ser ou significação (finalidade) a partir da posição que ocupa na relação com os outros instrumentos do conjunto do qual ele faz parte. O mundo enquanto contexto é um conjunto organizado segundo determinado momento histórico, nunca sendo fechado e definitivo, mas sempre aberto devido a certa plasticidade e maleabilidade segundo o contexto histórico e a cultura na qual se insere. É neste sentido que Levinas, em Humanismo do outro homem, afirma:

É esta noção de horizonte ou de mundo, concebido segundo o modelo de um contexto e, finalmente, de acordo com o modelo de uma linguagem e de uma cultura - com todo o aspecto de aventura e do "déjà fait" históricos que eles comportam - que é o lugar em que a significação se situa (LEVINAS, 2012, p. 20). 
A relação entre instrumento e mundo nos permite compreender tanto um primeiro nível da relação entre velamento e desvelamento como a concepção heideggeriana de fenômeno e, consequentemente, de fenomenologia. Para se compreender a relação entre velamento e desvelamento, é preciso ter em mente que Heidegger constrói seu conceito de verdade como desvelamento (Unverborgenheit) a partir de uma interpretação do termo grego aletheia. Ele insiste no fato de que, em grego, este termo possui uma origem negativa devido ao alpha privativo que corresponde ao $U n$ da palavra alemã $U n$-verborgenheit e ao des do termo português des-velamento ${ }^{9}$. Ao insistir na origem negativa do termo aletheia, Heidegger quer nos mostrar que primeiramente e na maior parte das vezes há um velamento constitutivo ao desvelamento do ente, ou seja, que em todo desvelar do ente como instrumento o mundo enquanto conjunto organizado de instrumentos segundo um contexto histórico permanece, primeiramente e na maior parte do tempo, velado, esquecido, daí porque Merleau-Ponty diz que "todo desvelamento de um ente é esquecimento daquilo que não é desvelado" (MERLEAU-PONTY, 1996, p. 100). É neste contexto que Heidegger define a tarefa de sua fenomenologia:

O que é isto que a fenomenologia deve 'fazer ver'? [...] Abertamente aquilo que primeiramente e na maior parte do tempo não se mostra, aquilo que está velado diante daquilo que se mostra primeiramente e na maior parte do tempo, mas que pertence, ao mesmo tempo, essencialmente àquilo que se mostra primeiramente e na maior parte das vezes, de tal modo que ele constitui seu sentido e fundamento (HEIDEGGER, 2001, p. 35).

Assim, se o ente se desvela primeiramente e na maior parte do tempo como instrumento que serve para realizar uma finalidade, o mundo, enquanto conjunto organizado de instrumentos que condiciona a aparição, o desvelamento do ente como instrumento, permanece velado. O mundo ou o ente na totalidade não é um ente (objeto ou coisa) que possa se desvelar e aparecer como os entes intramundanos (o mundo nunca se desvela do mesmo modo que a caneta ou a moeda, nunca encontraremos o mundo como encontramos uma caneta ou uma

9 Sobre a questão do alpha privativo do termo aletheia, conferir: Ser e tempo, §44, p. 222, Introdução à filosofia, GA 27, p. 79, Sobre a essência da verdade. O mito da caverna e o Teeteto de Platão, GA 34, p. 11. 
moeda). Logo, uma primeira função da fenomenologia heideggeriana é fazer ver, ou seja, desvelar aquilo que permanece primeiramente e na maior parte do tempo velado: o mundo ou o ente na totalidade. Para Heidegger, enquanto estamos no mundo das ocupações e tarefas cotidianas em que o ente se desvela como instrumento, o mundo enquanto ente na totalidade permanece velado, fechado, inacessível. No entanto, na disposição afetiva do tédio, por exemplo, em que todo e qualquer ente como instrumento perde seu interesse, e da angústia enquanto relação ao nada enquanto não-ente, abre-se a possibilidade de desvelamento do mundo enquanto tal, do ente na totalidade.

Como acabamos de ver, os conceitos de verdade como desvelamento e de $D a$ sein como ser-no-mundo são anteriores, constitutivos e originários em relação à verdade como adequação e ao esquema sujeito-objeto, que possuem o estatuto de posterior, constituído e, portanto, derivado. Neste sentido, a verdade e falsidade de uma proposição aparecem como derivadas em relação ao desvelamento do ente como instrumento e do velamento do mundo ou do ente na totalidade. Velamento e desvelamento não coincidem com falsidade e verdade. Tal relação entre velamento e desvelamento nos permite compreender que a tarefa da fenomenologia heideggeriana consiste, em larga escala e entre outras coisas, em faz ver, em desvelar aquilo que primeiramente e na maior parte do tempo permanece velado.

\section{A desconstrução da metafísica e o problema da verdade}

Para compreendermos a relação entre a verdade como adequação e a verdade como desvelamento, faz-se necessário compreender previamente a questão da desconstrução da metafísica no pensamento de Heidegger. O modo como compreendemos a questão da desconstrução é decisivo para entendermos não somente a relação entre estes dois conceitos de verdade, mas aquilo que está realmente em jogo na experiência intelectual do filósofo alemão. Isto porque as frequentes acusações de irracionalismo, niilismo, inimigo da lógica, antimetafísico dirigidas a Heidegger se fundam em quatro equívocos: 1) compreender a Destruktion limitando-se ao modo como ela é exposta no $§ 6$ de Ser e tempo. 2) compreender o termo de Destruktion no sentido ordinário da linguagem enquanto procedimento meramente negativo. 3) não levar em conta que a Destruktion consiste numa operação negativa e positiva. 4) compreender a Destruktion como uma forma de inversão (Umkehrung) da metafísica ou antimetafísica. 
Existe uma tendência hegemônica de se compreender a Destruktion principalmente tal qual ela é formulada no $§ 6$ de Ser e tempo, ou seja, dissociada dos dois outros momentos do método fenomenológico de Heidegger apresentado em Os problemas fundamentais da fenomenologia: redução e construção. Neste texto, Heidegger afirma: "Estes três momentos do método fenomenológico - redução, construção e Destruktion - são interdependentes em seu conteúdo e devem ser fundados em sua relação de interdependência” (HEIDEGGER, 2005, p. 31).

Para Heidegger, só compreenderemos suficientemente a Destruktion da metafísica se a apreendermos no interior de sua relação com as operações de redução e construção. Em que consiste a relação entre redução, construção e Destruktion? Ela consiste, grosso modo, em três operações solidárias: 1) a redução enquanto exigência filosófica de Voraussetzungslosigkeit (isenção de pressupostos) própria a todo pensar radical exige uma 2) construção como genealogia histórica dos pressupostos fundamentais do pensamento metafísico, pressupostos que consistem em um modo de se compreender o ser, a verdade, o pensamento, a linguagem e o homem. 3) a Destruktion, por fim, consiste por um lado em uma operação negativa de imposição de certos limites aos pressupostos fundamentais do pensamento metafísico, por outro em uma operação positiva e criativa de alargamento do modo como compreendemos o ser, a verdade, o pensamento, a linguagem e o homem.

A operação negativa da Destruktion enquanto imposição de certos limites à metafísica possui duas funções principais: 1) mostrar que os conceitos metafísicos de ser, verdade, pensamento, linguagem e homem se pretendem como única dimensão de tais conceitos. 2) mostrar que existe um reducionismo próprio à metafísica ao limitar tais conceitos a uma única dimensão. Esta operação negativa da Destruktion conduz Heidegger ao seu momento positivo: mostrar que existe outra dimensão do ser, da verdade, do pensamento, da linguagem e do homem e que esta dimensão é originária em relação ao domínio derivado da metafísica. Tomemos como exemplo nossa questão da verdade. A operação negativa da Destruktion consiste em mostrar que o conceito metafísico de verdade como adequação não é nem a única dimensão da verdade, nem sua dimensão originária. A função da operação positiva é nos mostrar que há outra dimensão da verdade enquanto desvelamento e que esta dimensão é originária em relação à verdade como adequação, visto ser a sua condição anterior de possibilidade. Isto não quer dizer que Heidegger destrói, no sentido de refutar, jogar fora, aniquilar, eliminar, o conceito de verdade como adequação. Tal verdade possui certa validade e legitimidade, no entanto limitada à medida que não é a única dimensão da verdade, nem mesmo sua dimensão originária. De modo que a 
partir do momento em que apreendemos a Destruktion na sua relação com a redução e a construção, que compreendemos que ela comporta uma operação negativa e positiva, e que a operação negativa não consiste em um simples destruir, eliminar, descartar, refutar, mas num estabelecimento de certos limites da metafísica, evitamos uma série de mal-entendidos em torno do pretenso irracionalismo, niilismo, antimetafísica e antilógica do pensamento de Heidegger. Para ele, desconstruir a metafísica não é invertê-la no sentido de falar em nome do irracional contra o racional, do nada contra o ser, do sensível contra o inteligível, do ilógico contra o lógico, mas de mostrar certo limite e reducionismo da metafísica e atingir uma dimensão do pensamento em que os dualismos entre racional e irracional, ser e nada, sensível e inteligível, lógico e ilógico são desativados e neutralizados. É por isso que Heidegger insiste, em diversos lugares, que a inversão da metafísica ainda é metafísica, pois, somente inverte a relação hierárquica de valor de um dualismo operando no interior de tal dualismo como se fosse algo dotado de autoevidência e obviedades não problemáticas. Em Carta sobre o humanismo, Heidegger afirma: "a inversão [Umkehrung] de uma proposição metafísica permanece uma proposição metafísica" (HEIDEGGER, 2004d, p. 328). Neste mesmo sentido ele afirma em Quem é o Zaratustra de Nietzsche?:

O pensamento metafísico se funda na diferença entre aquilo que é verdadeiro, e aquilo que, mensurado ao primeiro, constitui o ente não verdadeiro. Para a essência da metafísica, o decisivo não reside de modo algum na dita diferença que se apresenta como oposição entre o sensível e o inteligível, mas que esta diferença permaneça o dado primeiro e a base no sentido de uma corte primeiro. Ela também continua a existir mesmo quando a hierarquia platônica entre o sensível e o inteligível é invertida (umgekehrt) (HEIDEGGER, 2009, p. 118).

Após tais esclarecimentos sobre a Destruktion da metafísica em Heidegger, a fim de evitar certos equívocos e mal-entendidos, devemos ter em mente os seguintes aspectos: 1) a Destruktion não é uma operação isolada, mas deve ser compreendida em sua relação com a redução e a construção. A redução consiste na exigência filosófica de isenção de pressupostos naturalizados do pensamento. A construção, por sua vez, é uma genealogia da proveniência histórica dos pressupostos fundamentais do pensamento metafísico. E a desconstrução, por 
fim, é entendida como crítica dos pressupostos fundamentais da metafísica. 2) A desconstrução enquanto crítica da metafísica não é uma mera operação negativa de refutação, destruição e eliminação da metafísica. Ela comporta uma operação negativa de estabelecimento de certos limites à metafísica. Impor certos limites à metafísica significa, neste contexto, que a metafísica reduz o ser, a verdade, o pensamento, a linguagem e o homem a uma única dimensão. A operação positiva consiste em mostrar duas coisas: que há uma dimensão do ser, da verdade, do pensamento, da linguagem e do homem além da dimensão metafísica e que esta outra dimensão é originária enquanto condição de possibilidade da dimensão derivada da metafísica. 3) A desconstrução não coincide com uma inversão ou antimetafísica, mas em uma dimensão do pensamento que desativa as oposições e dualismos pressupostos como evidentes por todo modo de inversão e antimetafísica. Isto posto, podemos compreender melhor a relação entre o conceito metafísico de verdade como adequação e o conceito heideggeriano de verdade como desvelamento. Desconstruir a verdade como adequação não significa refutar, destruir ou eliminar tal conceito, nem inverter a relação entre verdade e falsidade afirmando que a falsidade está acima da verdade. Desconstruir a verdade como adequação significa mostrar que esta não é a única dimensão da verdade e nem mesmo o seu sentido originário, visto que há outra dimensão da verdade enquanto desvelamento que é originária enquanto condição de possibilidade da verdade como adequação. Assim, a verdade como adequação continua possuindo sua validade, legitimidade e direito de cidadania, no entanto num sentido mais limitado à medida que não é nem a única dimensão da verdade, nem o seu modo originário de manifestação.

\section{Arte e experiência do ser}

A delimitação do conceito metafísico de verdade como adequação, do conceito de verdade como desvelamento e da relação existente entre ambos a partir da noção de Destruktion nos permite retornar à tese de Badiou a fim de entendermos como se dá a relação entre arte, filosofia e verdade no pensamento de Heidegger. Para Badiou, a hermenêutica heideggeriana é romântica no sentido de que só a arte é capaz da verdade. No entanto, após analisarmos o problema da verdade no pensamento de Heidegger, somos conduzidos à ideia de que as coisas não se passam assim na sua filosofia. Para o filósofo alemão, a filosofia como metafísica e a ciência são dois regimes discursivos proposicionais capazes de atingir a verdade como adequação, ou seja, a tese de que para Heidegger 
só a arte é capaz da verdade não se sustenta. No entanto, embora a filosofia como metafísica e a ciência sejam capazes de atingir a verdade como adequação, só o pensamento do ser e a arte enquanto setor da physis são capazes da verdade como desvelamento. Assim, a partir da distinção entre estes dois níveis de verdade, a filosofia enquanto metafísica e a ciência são capazes da verdade como adequação e o pensamento do ser e a arte da verdade como desvelamento.

Neste sentido, a tarefa do pensamento do ser e da arte consiste em nos fazer ver, em desvelar aquilo que primeiramente e na maior parte do tempo permanece velado. Como vimos, à medida que o ente enquanto instrumento se desvela, o mundo enquanto ente na totalidade permanece velado. No texto $A$ origem da obra de arte, Heidegger se serve de um quadro de Van Gogh para falar sobre o acontecimento da verdade como desvelamento do mundo ou do ente na totalidade na pintura:

\begin{abstract}
No quadro de Van Gogh acontece a verdade. Isto não quer dizer que aqui algo Vorhandenes seja corretamente representado pela pintura, mas que no tornar-se aberto do ser instrumento, o sapato-instrumento atinge o ente na totalidade, mundo e terra em seu jogo de reflexos, em seu desvelamento (HEIDEGGER, 1980, p. 41).
\end{abstract}

A obra de arte desvela aquilo que primeiramente e na maior parte do tempo permanece velado no mundo das ocupações e tarefas cotidianas: o mundo enquanto ente na totalidade. No entanto, dizer isto ainda é dizer pouco, pois, neste nível de interpretação ainda não nos situamos totalmente na dimensão daquilo que está realmente em jogo no pensamento de Heidegger, pois, o que está realmente em jogo no pensamento heideggeriano do ser e na obra da arte é o desvelamento do mundo e do ente na totalidade à medida que este nos abre à possibilidade daquilo que Heidegger chama de Erfahrung des Seins (experiência do ser). Em outros termos, aquilo que está realmente em jogo no pensamento de Heidegger é o desvelamento do ser dos entes que nos abre para uma experiência do ser. Neste sentido, Merleau-Ponty afirma, acertadamente, que "através do pensamento do ser, Heidegger quer encontrar, contra a metafísica, a experiência do Ser (l'expérience de l'Être)" (MERLEAUPONTY, 1996, p. 101). No Posfácio a "O que é metafísica?", Heidegger descreve tal experiência do ser do seguinte modo: "Só o homem entre todos os entes experimenta, chamado pela voz do ser, a maravilha de todas as maravilhas: que o ente é (...). A 
clara coragem para a angústia essencial esconderia a possibilidade misteriosa da experiência do ser [Erfahrung des Seins]" (HEIDEGGER, 2004e, p. 307). No texto $O$ que é metafísica?, Heidegger se refere a esta mesma experiência do ser que se dá no nada da angústia:

\begin{abstract}
Somente na clara noite do nada da angústia surge a abertura originária do ente enquanto tal: 'que o ente é algo e não nada'. Este 'e não nada' acrescentado ao discurso não é, no entanto, um esclarecimento suplementar mas o tornar possível prévio da abertura do ente em geral. A essência do nada nadificante originário reside no seguinte: ele traz o Dasein pela primeira vez diante do ente enquanto tal (HEIDEGGER, 2004e, p. 114).
\end{abstract}

Quando o mundo se desvela como ente na totalidade, abre-se a possibilidade de sermos conduzidos à pergunta: "Por que há o mundo ao invés de nada?", "porque que há algo ao invés de nada?". A fim de compreender a função desta questão no pensamento de Heidegger, uma observação preliminar é necessária. Uma distinção fundamental estabelecida por Heidegger consiste em um modo metafísico e um modo não metafísico de colocar a pergunta "Por que há algo ao invés de nada?". O modo metafísico-filosófico de pôr tal questão pode ser chamado de "causal", no sentido de que através desta questão se parte em busca de uma causa primeira do ente na totalidade como, por exemplo, o primeiro motor de Aristóteles, o Deus como causa sui de Espinosa ou o Deus de Descartes e Leibniz. Para Heidegger, "à medida que esta pergunta questiona de modo causal ainda no modo dominante da metafísica como fio condutor do porquê, o pensamento do ser é completamente negado em nome do conhecimento que representa o ente a partir do ente" (HEIDEGGER, 2004e, p. 381). Ou seja, enquanto se pergunta metafisicamente de modo causal, renuncia-se ao pensamento do ser em nome do pensamento do ente na totalidade como sendo causado por um ente supremo. $\mathrm{O}$ ente na totalidade remete ao caráter ontológico da metafísica enquanto determinação da entidade (Seiendheit) comum a todos os entes. $\mathrm{O}$ ente supremo corresponde ao aspecto teológico da metafísica enquanto determinação do ente supremo como razão de ser de todos os entes. Daí a famosa tematização da essência da metafísica enquanto ontoteologia. Além do modo metafísico-filosófico de colocar a questão "por que há algo ao invés de nada?", há ainda um modo metafísico-religioso de pôr tal questão. O 
modo metafísicoreligioso guarda uma semelhança de família com o aspecto teológico da metafísica filosófica na medida em que permanece no âmbito do ente enquanto ente criado por um ente supremo (Deus criador), possuindo uma resposta à questão antes mesmo de colocá-la:

Para quem, por exemplo, a bíblia é abertura divina e verdade, a pergunta 'por que existe em geral o ente e não antes nada?' já possui uma resposta antes mesmo de toda formulação da questão: o ente, à medida que não é o próprio Deus, é criado por ele. O próprio Deus 'existe' enquanto criador incriado. Quem permanece neste solo pode, claro, repetir e, de certo modo, enunciar conosco o questionar da nossa questão, mas não pode questionar autenticamente sem renunciar a si mesmo enquanto crente com todas as consequências deste passo (HEIDEGGER, 1983, p. 8-9)

A questão “por que há algo ao invés de Nada?” no pensamento de Heidegger seria mal entendida se a compreendêssemos no sentido metafísico da pergunta causal que busca um ente supremo como causa do ente na totalidade. Será que Heidegger retoma a questão "por que há algo ao invés de nada?" segundo o modo metafísico "ou a pergunta é colocada em um sentido totalmente outro? Se ela não pergunta pelo ente para anunciar o ente primeiro como causa do ente, então a pergunta deve partir daquilo que não é um ente. A pergunta nomeia e escreve com maiúscula um tal [não ente]: o Nada" (HEIDEGGER, 2004e, p. 382). Assim, quando Heidegger retoma a pergunta "por que há algo ao invés de Nada?", ele não está em busca de um ente supremo que explique a existência do ente na totalidade, pois seu pensamento se situa numa dimensão para além do ente apontando para o sem fundo do abismo do nada. Embora Bergson faça uma crítica do nada e da questão "por que há algo ao invés de nada?", sua reflexão nos ajuda a entender melhor aquilo que está em jogo no modo heideggeriano de colocar tal questão. Em O pensamento e o movente, Bergson diz:

Tal é o problema da origem do ser: 'como pode acontecer que algo exista - matéria, espírito, ou Deus? Foi preciso uma causa, e uma causa da causa, e assim por diante indefinidamente.' Remontamos então de causa em causa; e 
se paramos em algum lugar, não é que a nossa inteligência não procure mais nada além, é que nossa imaginação acaba fechando os olhos, como sobre o abismo, para escapar da vertigem (BERGSON, 2013, p. 65).

O modo heideggeriano de colocar a questão "por que há algo ao invés de Nada?" quer nos dizer mais o menos o seguinte: poderiam não existir plantas, animais, vegetais, mares, o céu, a terra, os planetas, as pessoas, e, no entanto, tudo isso existe!!! Quando nos damos conta de que tudo o que existe poderia não existir sendo um grande vazio, um "imenso" nada sem terra nem céu, sem estrelas nem animais, sem plantas nem minerais, sem pessoas nem história, ficamos perplexos e espantados diante do fato de que possa haver tudo isso ao invés de nada. Segundo Bergson, "[n]unca, com efeito, a gente se espantaria com o fato de que algo existe - matéria, espírito, Deus -, se a gente não admitisse implicitamente que poderia não existir nada" (BERGSON, 2013, p. 65). A questão "por que há algo ao invés de Nada?" abre a possibilidade do desvelamento do ser do mundo, do ser do ente na totalidade. A experiência do ser é a experiência do mistério de que existe algo ao invés de nada. Tal experiência do ser é revelada por uma série de disposições afetivas que poderíamos descrever como angústia, perplexidade, espanto, admiração, vertigem, maravilhamento e terror diante do ser do ente, ou seja, do fato de que tudo que existe existe, sendo que poderia não existir nada. É neste sentido que enunciar e escutar simplesmente a pergunta "por que há algo ao invés de Nada?” ainda não é colocá-la no sentido forte do termo. Só colocamos realmente tal questão quando entramos no estado de espírito de tal questão. Entrar no estado de espírito de tal questão é ser tomado pelas disposições afetivas da angústia-perplexa-espantada-admirativa-vertiginosa-maravilhada-aterrorizada diante do ser do ente. Para Heidegger, a pergunta "Por que existe em geral o ente e não antes Nada? [...] é claramente a primeira de todas as perguntas", no entanto, "[...] muitos nunca se deparam com esta pergunta, se isso deve significar, não apenas escutar e ler a questão enunciada, mas: perguntar a pergunta, isto é entrar no estado de espírito dela, colocá-la respondendo à exigência do estado desta questão" (HEIDEGGER, 1983, p. 3). A principal função da questão "por que há algo ao invés de Nada?" no pensamento de Heidegger é de nos abrir para a experiência do ser. É neste contexto que podemos compreender a seguinte passagem: a pergunta “"[p] or que existe em geral o ente e não antes Nada?' nos convoca à questão que na ordem das questões é a mais ampla, a mais profunda e a 
mais originária” (HEIDEGGER, 1983, p. 4). Tal questão é a mais ampla pois não se restringe a nenhum ente específico questionando o ente em sua totalidade. Ela é a mais profunda porque ao buscar as causas primeiras do ente não se depara com um outro ente como o Deus causa sui no fundo no ente, mas com aquilo que não é um ente, ou seja, o abismo do nada que nos impede de compreender por que há algo ao invés de nada a partir de um ente supremo. Ela é, por fim, a mais originária porque nos abre a possibilidade da experiência do ser, que primeiramente e na maior parte do tempo permanece velada, fechada, inacessível. Segundo Jean Grondin, Heidegger sempre retorna à esta experiência do ser ao longo de toda a sua obra:

Heidegger sempre retornou a esta experiência do ser (Erfahrung des Seins), sim, a este espanto (Erstaunen) diante do ser, que nós não 'produzimos', mas no qual somos, mas apenas por um instante mortal que nos sufoca (...) esta maravilha de todas as maravilhas (...) que o ente é, que há algo - e nós - e não antes nada. Esta experiência é - simples e claramente - a do ser para Heidegger. Ela só pode ser temporal e uma experiência daquilo que se retira e permanece inapreensível através de conceitos (GRONDIN, 2007, p. 6).

Após estes esclarecimentos sobre a questão "por que existe o ente em geral e não antes Nada?" e sua relação com a experiência do ser na filosofia de Heidegger, já possuímos todos os elementos para compreender a relação entre arte, filosofia e verdade em seu pensamento. A filosofia como metafísica e a ciência são, contrariamente ao que pensa Badiou, capazes da verdade como adequação para Heidegger, visto serem regimes de discurso que enunciam proposições que descrevem corretamente o estado de coisas do mundo. $O$ pensamento do ser $\mathrm{e}$ a arte também são capazes de alcançar a verdade, porém não como adequação, mas como desvelamento. Elas alcançam a verdade como desvelamento em dois níveis distintos: 1) o desvelamento do mundo ou do ente na totalidade, que permanece primeiramente e na maior parte do tempo velado. 2) o desvelamento do mundo ou ente na totalidade nos abre a possibilidade do desvelamento do ser do mundo ou do ser do ente na totalidade. Neste segundo sentido, trata-se da experiência do ser descrita acima, daí porque a fenomenologia de Heidegger não se limita ao desvelamento do mundo ou do ente na totalidade, mas do ser do ente que primeiramente e na maior parte das vezes permanece velado: 
O que é isto que a fenomenologia deve 'fazer ver'? [...] Abertamente aquilo que primeiramente e na maior parte do tempo não se mostra, aquilo que está velado diante daquilo que se mostra primeiramente e na maior parte do tempo, mas que pertence, ao mesmo tempo, essencialmente àquilo que se mostra primeiramente e na maior parte das vezes, de tal modo que ele constitui seu sentido e fundamento. No entanto, o que permanece velado (verborgen) em um sentido profundo ou que recai no encobrimento ou que se mostra apenas 'dissimulado' não é este ou aquele ente, mas [...] o ser do ente (HEIDEGGER, 2001, p. 35)

Assim, a obra de arte seria, para Heidegger, um locus privilegiado do desvelamento do ser do ente e, portanto, da experiência do ser, da experiência de que o ente é algo ao invés de nada. Este é o ponto crucial do pensamento heideggeriano do ser. O seguinte trecho de $A$ origem da obra de arte não poderia ser mais claro quanto à função de desvelamento do ser e da experiência do ser na arte:

Mas o que é mais banal do que isto, que o ente é? $\mathrm{Na}$ obra [de arte], ao contrário, o fato de que o ente enquanto tal é, é o menos banal (...). Quanto mais essencialmente a obra se abre, tanto mais luminosa se torna a unicidade de que o ente é ao invés de nãoser. Quanto mais essencialmente este impacto vem ao aberto, tanto mais estranha e única se torna a obra. Na produção do ser da obra reside este colocar em cena do 'que o ente é' (HEIDEGGER, 1980, p. 52).

No mundo das ocupações cotidianas, o mundo enquanto ente na totalidade e o ser do ente na totalidade permanecem, primeiramente e na maior parte do tempo, velados, pois, "o ente ama se velar em seu ser" (HEIDEGGER, 1988, p. 13). Com isso, o ser do ente passa por aquilo que há de mais banal e natural do mundo, não nos chamando a atenção nem despertando as disposições afetivas da angústia, perplexidade, espanto, vertigem, maravilhamento e terror próprias à experiência do ser. Na verdadeira obra de arte, ao contrário, o ser do ente per- 
de toda sua banalidade e familiaridade aparecendo como estranho, como aquilo que há de menos banal e familiar. É neste sentido que Heidegger diz: "No poetizar do poeta e no pensar do pensador, o espaço do mundo é sempre organizado tão cuidadosamente, que nele toda e qualquer coisa, uma árvore, uma montanha, uma casa, um canto de pássaro perde totalmente a sua indiferença e banalidade" (HEIDEGGER, 1983, p. 28-29). Primeiramente e na maior parte do tempo o ser do ente se vela, se retrai tornando o fato do ente ser aquilo que há de mais banal, familiar e indiferente. Normalmente somos como o belo senhor (beau monsieur) de A náusea de Sartre: "O belo senhor existe. O senhor sente que existe. Não, o senhor que passa, suave e orgulhoso [...] não sente que existe. Expandir-se: minha mão cortada que dói existe, existe, existe" (SARTRE, 2011, p. 147). O belo senhor de $A$ náusea não sente que existe, que tudo que existe existe sendo que poderia não existir. A atitude do belo senhor é a atitude que temos primeiramente e na maior parte das vezes: tomar o ser e a existência dos entes como algo banal e familiar que não nos chama a atenção nos deixando indiferentes. O recurso que Sartre utiliza em A náusea para nos tirar desta atitude primeira de indiferença em relação ao ser e a existência de tudo o que existe a fim de nos abrir para a experiência do ser é a repetição exaustiva da palavra "existir", como no trecho "minha mão cortada que dói existe, existe, existe".

Além de Heidegger e Sartre, Lacan também sabia que primeiramente e na maior parte do tempo tentamos nos esquivar e fugir desta experiência quase insuportável do ser, que de tão angustiante nos deixa perplexos e aterrorizados, nos faz sentir a vertigem de se estar diante de um abismo. Embora o vocabulário de Lacan seja estranho ao de Heidegger, visto que o psicanalista francês não fala em termos de Dasein e ser, mas de sujeito e presença, ele tem em mente aquilo que Heidegger chama de experiência do ser:

[...] no ponto mais sensível [...] o sujeito o sente como a brusca percepção de algo que não é fácil de definir, a presença. Está aí um sentimento que não temos o tempo todo. Claro, somos influenciados por todos os tipos de presenças, e nosso mundo só possui sua consistência, sua densidade, sua estabilidade vivenciada porque, de certo modo, levamos em conta estas presenças, mas não a percebemos como tais. Vocês sentem bem que é um sentimento do qual eu diria que nós tendemos constantemente a apagar da vida. Não seria fácil de viver se, a todo instante, tivéssemos o sentimento da presença com 
tudo que ela comporta de mistério. É um mistério do qual nos distanciamos, e do qual, para dizer tudo, somos feitos (LACAN, 1975, p. 53).

Heidegger, Sartre e Lacan trouxeram a experiência do ser à palavra. Há alguns anos venho desenvolvendo um trabalho de articulação entre Heidegger, Fernando Pessoa e a questão da experiência do ser. A ideia de articular Heidegger e Fernando Pessoa surgiu da leitura do capítulo "Uma tarefa filosófica: ser contemporâneo de Pessoa" do livro Pequeno manual de inestética de Alain Badiou. Neste texto, ele diz:

Pessoa, morto em 1935, só se tornou conhecido na França, de modo mais amplo, cinquenta anos mais tarde. Eu me incluo neste atraso escandaloso. Trata-se de um dos poetas decisivos do século, e singularmente, se se tenta pensá-lo como condição possível da filosofia. A questão pode, com efeito, se formular assim: a filosofia deste século, incluindo a dos últimos dez anos, conseguiu, soube, se colocar à altura do empreendimento poético de Pessoa? [...] é preciso, então, concluir que a filosofia não está, ainda não está à altura de Pessoa. Ela não pensa ainda $\grave{a}$ altura de Pessoa (BADIOU, 2011, p. 61-62)

Desta tarefa filosófica enunciada por Badiou surgiu a ideia de articular filosofia heideggeriana e poesia pessoana a fim de mostrar que Pessoa traz à palavra poética a experiência do ser à qual Heidegger sempre retorna ao longo de toda a sua experiência intelectual. A minha tese é de que certos poemas de Álvaro de Campos elevam a experiência do ser à linguagem em sua forma mais bem acabada e elaborada no interior da história contemporânea do pensamento e da poesia. Em outras palavras, Álvaro de Campos possui todo um poetizar sobre o ser nos oferecendo uma experiência privilegiada e poética do ser. Os seguintes trechos do poema intitulado "Ah, perante esta única realidade, que é o mistério" são o ponto mais alto da poesia de Fernando Pessoa sobre a experiência do ser:

Ah, perante esta única realidade, que é o mistério,

Perante esta única realidade terrível - a de haver uma 
realidade,

Perante este horrível ser que é haver ser,

Perante este abismo de existir um abismo,

Este abismo de a existência de tudo ser um abismo,

Ser um abismo por simplesmente ser,

Por poder ser,

Por haver ser!

Perante isto tudo como tudo o que os homens fazem,

Tudo o que os homens dizem,

Tudo quanto constroem, desfazem ou se constrói ou desfaz através dele,

Se empequena!

Não, não se empequena... se transforma em outra coisa Numa só coisa tremenda e negra e impossível,

Uma coisa que está para além dos deuses, de Deus, do Destino -

Aquilo que faz que haja deuses e Deus e Destino,

Aquilo que faz que haja ser para que possa haver seres, Aquilo que subsiste através de todas as formas,

De todas as vidas, abstractas ou concretas,

Eternas ou contingentes,

Verdadeiras ou falsas!

Aquilo que quando se abrangeu tudo não se abrangeu explicar porque é um tudo,

Porque há qualquer coisa, porque há qualquer coisa, porque há qualquer coisa!

[...] E deste medo, desta angústia, deste perigo do ultra-ser, Não se pode fugir, não se pode fugir, não se pode fugir!

[...] Porque não afrontei sorridente, inconsciente, a Morte? Ignoro-a? Mas que é que eu não ignoro? A pena em que pego, a letra que escrevo, o papel em que escrevo, 
São mistérios menores que a Morte? Como se tudo é o mesmo mistério? [...]

Ah, afronte eu como um bicho a morte que ele não sabe que existe!

Tenha eu a inconsciência profunda de todas as coisas naturais,

Pois, por mais consciência que tenha, tudo é inconsciência, Porque é preciso existir para se criar tudo,

E existir é ser inconsciente, porque existir é ser possível haver ser,

E ser possível haver ser é maior que todos os Deuses (PESSOA, 2002, p. 256-257)

\section{Conclusão}

Segundo Badiou, os três esquemas hegemônicos e dominantes de compreensão da relação entre arte, filosofia e verdade no interior da história da filosofia são didatismo, romantismo e classicismo. Para o didatismo só a filosofia é capaz de alcançar a verdade, ou seja, a arte é incapaz de verdade. Para o romantismo, ao contrário, só a arte é capaz de revelar a verdade, o que significa que a filosofia é incapaz da verdade. Para o classicismo, o fato de a arte não ser capaz da verdade não é um problema, pois sua função não é revelar a verdade, mas um tratamento terapêutico das afecções da alma. Segundo o esquema de Badiou, Heidegger possuiria uma forma romântica de compreender a relação entre arte, filosofia e verdade. No entanto, a partir da distinção entre verdade como adequação e verdade como desvelamento e a relação existente entre ambas a partir da noção de desconstrução, tentei mostrar ao longo deste artigo que tal tese de Badiou é equivocada porque, para Heidegger, tanto a filosofia enquanto metafísica e a ciência são, sim, capazes de alcançar a verdade em sua dimensão de adequação. Já o pensamento do ser e a arte enquanto setor da physis são capazes de revelar a verdade como desvelamento.

Para Heidegger, existe uma relação de hierarquia entre a verdade como adequação e a verdade como desvelamento a partir do critério do constitutivo e originário e do constituído e derivado. A verdade como desvelamento é, digamos, superior à verdade como adequação à medida que é mais originária enquanto 
condição de possibilidade da verdade como adequação. Tudo se passa como se a verdade enquanto adequação de nosso discurso proposicional argumentativo estabelecido pela razão fosse de algum modo uma verdade menor em relação a uma verdade que não possui a modalidade do discurso argumentativo e que nos possibilita certo modo de experiência poético-artística do encantamento e do ser que se esgota em seu simples estar-aí não necessitando ser fundado no discurso argumentativo. $\mathrm{Na}$ arte, trata-se de uma verdade que se situa além da faculdade de compreensão e entendimento de um sujeito diante de um discurso que fala sobre algo enquanto descrição correta da realidade. É neste sentido que Clarice Lispector diz: "Não se compreende música: ouve-se. Ouve-me então com o teu corpo inteiro" (LISPECTOR, 1976, p. 9). Tudo se passa como se a verdade de proposições filosóficas e científicas do tipo "o eu é um sujeito que pensa", "a matéria é uma substância da realidade", "o sol é o centro do universo", "a água é um composto de H20", etc., fosse uma dimensão da verdade totalmente outra em relação à verdade de quando, por exemplo, escutamos uma música que nos encanta nos levando ao êxtase, ou quando vemos um quadro que nos fascina causando maravilhamento, ou quando lemos uma poesia que nos eleva à experiência do ser. Talvez apenas nesses raros momentos em que a arte se desvela como verdade que podemos, pelo sopro de um instante efêmero, habitar poeticamente sobre a Terra. Nietzsche, assim como Heidegger, também acreditava nesta dimensão não discursiva e argumentativa da arte como superior ao modo lógico, discursivo e argumentativo da ciência e da metafísica, daí porque "apenas como fenômeno estético a existência e o mundo são eternamente justificados" (NIETZSCHE, 2004, p. 41).

AQUIN, T. Somme théologique. Paris, Cerf, 1999.

ARISTOTE. Métaphysique. Paris, Les Belles Lettres. . Poétique. Texte bilingue. Tr. Barbara Gernez. Paris, Les Belles Lettres, 2002. . Sur l'interprétation. Texte bilingue. Tr. Pierre Pellegrin \& Michel Crubellier. Paris, Flammarion, 2007. 2011

BERGSON, H. La pensée et le mouvent. $17^{\mathrm{a}}$ edição. Paris, PUF, 2013.

DELEUZE, G. Différence et répétition. $12^{\mathrm{a}}$ edição. Paris, PUF, 2011.

FREUD, S. Neue Folge der Vorlesungen zur Einführung in die Psychoanalyse. GW 15, Frankfurt am Main, Fischer, 1990.

GRONDIN, J. Die Wiedererweckung der Seinsfrage auf dem Weg einer phänomenologischhermeneutischen 
Destruktion. In: Martin Heidegger: Sein und Zeit, org. Thomas Rentsch. Berlin, Akademie, 2007.

HEGEL, G.W.F. Enzyklöpedie der philosophischen Wissenschaften I. $6^{\text {a }}$ edição. Frankfurt am Main, Suhrkamp, 2003.

HEIDEGGER, M. Brief über den Humanismus. $7^{\mathrm{a}}$ edição. In: Wegmarken. $3^{\text {a }}$ edição. Frankfurt am Main, Klostermann, 2004.

. Einführung in die Metaphysik. GA 40. Frankfurt am Main, Klostermann, 1983.

. Der Ursprung des Kunstwerkes, In: Holzwege. $6^{\text {a }}$ edição. Frankfurt am Main, Klostermann, 1980.

. Die Grundprobleme der Phänomenologie. $3^{\mathrm{a}}$ edição. Frankfurt am Main, Klostermann, 2005.

. Platons Lehre von der Wahrheit. In: Wegmarken. $3^{\text {a }}$ edição. Frankfurt am Main, Klostermann, 2004a.

. Sein und Zeit. $18^{\mathrm{a}}$ edição. Tübingen, Max Niemeyer, 2001.

. Vom Wesen des Grundes. In: Wegmarken. $3^{\mathrm{a}}$ edição. Frankfurt am Main, Klostermann, 2004b.

. Vom Wesen der Wahrheit. In: Wegmarken. $3^{\mathrm{a}}$ edição. Frankfurt am Main, Klostermann, 2004c.

. Vom Wesen der Wahrheit. Zu Platons Höhlengleichnis und Theätet. GA 34. Frankfurt am Main, Klostermann, 1988.

. Was ist Metaphysik?. In: Wegmarken. $3^{\mathrm{a}}$ edição. Frankfurt am Main, Klostermann, 2004e.

. Wer ist Nietzsches Zarathustra?. In: Vorträge und Aufsätze. 11 a edição. Stuttgart, Klett-Cotta, 2009.

JAMES, W. O pragmatismo. In: Os pensadores. Tr. Jorge Caetano da Silva \& Pablo Rubén Mariconda. São Paulo, Abril Cultural, 1979.
KANT, E. Critique de la raison pure. Tr. Alexandre J.L. Delamarre \& François Marty. Paris, Gallimard, 2002.

LACAN, J. Le séminaire I - Les écrits techniques de Freud. Paris, Seuil, 1975.

LEVINAS, E. Humanisme de l'autre homme. 6 a edição. Paris, Fata Morgana, 2012.

LISPECTOR, C. Água viva. $2^{\mathrm{a}}$ edição. São Paulo, Círculo do Livro, 1976.

MERLEAU-PONTY, M. Notes de cours: 1959-1961. Paris, Gallimard, 1996.

NIETZSCHE, F. Die Geburt der Tragödie. Stuttgart, Reclam, 2004.

PESSOA, F. PoesialÁlvaro de Campos. São Paulo, Companhia das Letras, 2002.

PLATON. Cratyle. Tr. Émile Chambry. Paris, Flammarion, 1967.

La république. Tr. Georges Leroux. Paris, Flammarion, 2002.

. Sophiste. Tr. Émile Chambry. Paris, Flammarion, 1969.

SARTRE, J.-P. La nausée. Paris, Gallimard, 2011.

WITTGENSTEIN, L. Tractatus Logico-Philosophicus. Edição bilingue alemão-inglês. London, Routledge \& Kegan Paul, 1961.

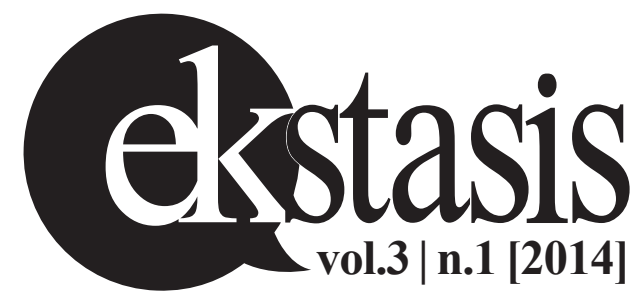

